\title{
Prospects for the spatial development of regions based on the principles of passportization of tourist and recreational destinations
}

\author{
Valentina Varivoda ${ }^{1}{ }^{*}$ \\ ${ }^{1}$ Stavropol State Agrarian University, Zootechnical lane 12, Stavropol, 355000, Russia
}

\begin{abstract}
From the point of view of a systematic approach, the issues of organizing tourist and recreational space determine the directions of the functioning of the region and the mechanisms of participation of state, regional and municipal structures today. The author considers the tourist and recreational space as an object of regional policy of the constituent entities of the Russian Federation in the article. The basic element of the tourist and recreational spatial system is proposed to consider a tourist and recreational destination that attracts tourists. In the methodological aspect, the principles of passportization of tourist and recreational destinations serve as the basis for a single digital platform for the development of tourism throughout the country. In the era of digitalization and modern conditions of regional development, a tourist and recreational is relevant from the point of view of management principles. It will also allow systematizing data on the state of tourist and recreational resources of the territory and the natural and anthropogenic factors affecting them, which has the prospect of establishing statistical accounting at the municipal level and the possibility of systematic monitoring of indicators of tourism performance.
\end{abstract}

\section{Introduction}

The scientific problem of spatial development of territories and some of its aspects are reflected in numerous works of Russian and foreign researchers A huge contribution to the development of the studied direction of science was made by the works of famous researchers: A.G. Granberg, as well as V.V. Akberdina, E.G. Animitsa, V.N. Knyaginina, Yu.G. Lavrikova, P.A. S. A. Suspitsyna, A. I. Tatarkina, foreign scientists J. Thünen, V. Kristalller, M. Porter, M. Kramer, F. Hanson, D. Forey, B. Hall. Almost in all scientific developments of domestic and foreign specialists, the need to study and use the spatial factor in the development of plans and forecasts of the socio-economic development of the country, regions and municipalities is emphasized. One of the main aspects of scientific and practical activity in the tourism sector is the study of the peculiarities of its spatial development, but there is no systematic approach to solving this issue in the literature, the

\footnotetext{
* Corresponding author: Vvalensia@mail.ru
} 
hierarchy of subordination of the levels of the tourist and recreational system as a whole is not clear.

Almost all over the world, the subjects of the tourism sector and its individual objects faced with the problem of using the recreational potential of the tourist space, as well as the organization, development of the territories where they are based and often solve it without relying on existing scientific achievements, the hierarchy of subordination of the levels of the tourist and recreational system as a whole is not clear.

Particular attention should be paid to a systematic approach with all the variety of approaches to the problems being solved, since it is he who will allow to holistically considering the totality of connections and relationships of elements, their compositions, factors and conditions, the external environment, taking into account goal setting.

\section{Materials and methods}

In the modern period of the formation of new strategic documents on the development of the tourism and hospitality industry in space, the relevance of regional policy is due to the following aspects in the field of tourism and recreation:

- maintaining the image and building a brand of tourist areas in space;

- the establishment of an effective partnership of all participants in the tourism market (manufacturers of tourism products, catering facilities, accommodation facilities, local and regional authorities, etc.);

- formation of a strategy for the development of tourism and its individual regions, taking into account the infrastructural and resource component;

- building a vertical of state regulation of the development of national tourism in space, both top-down and bottom-up;

- building relationships between the state and its subjects in the development of tourism and recreation in space, the development of the interests of the state and municipalities in the subjects of the federation;

- reduction of socio-economic imbalances between regions based on the development of tourism potential;

- the development, first of all, of domestic and inbound tourism and, as a consequence, the priority of raising the standard of living of the population in the space of Russian regions.

The issues of deep study of the spatial aspects of the development of territories at the state level were first declared in the Federal Law «On Strategic Planning in the Russian Federation» dated June 28, 2014, No. 172 and in the «Strategy for the Spatial Development of the Russian Federation for the Period up to 2025» approved by the order of the Government of the Russian Federation for the period until 2025 dated February 13. 2019 $[1,2]$. Thanks to the adoption of these regulations, systemic changes have occurred in the main areas of strategic planning. The general limits of strategizing were established, taking into account the spatial factor, and the importance of developing strategic planning documents at the federal and regional levels was determined. It should be noticed that Article 39 of the Federal Law No. 172 also enables municipalities to carry out strategic planning of their territories if there is an appropriate decision on the part of local selfgovernment bodies [1].

\section{Results}

From the point of view of a systematic approach, the issues of organizing the tourist and recreational space determine the directions of the functioning of the region, as well as the 
mechanisms of participation of state, regional and municipal structures. This approach to the organization of tourist and recreational space is defined as a cluster policy [3].

Space, being a form of existence of matter, has certain distinctive features within the geographical envelope, which in turn determine the spatial organization of various spheres of human life on our planet:

- heterogeneity (all objects differ in origin);

- continuity (the presence of special discrete formations);

- orderliness (systematization and classification);

- dynamism (striving for existence in time and development in space);

- metricity (measurability of parameters in space);

- topology (binding to the territory in the coordinate plane);

- toponymy (presence of a name), etc.

Space is heterogeneous. It changes because it is determined by the interaction of various subjects and objects.

Thus the tourist and recreational geospace, being one of the private types of space, is a part of the territorial tourist and recreational system of the corresponding structural level of the hierarchy (local, regional, national, global) [4]. Consequently, the question of the structure of the tourist and recreational system is also timely, it seems impossible to consider the issues of spatial development of tourism both at the municipal, regional and federal levels without the solution of this question.

Space is a system of interconnected and interacting objects. That is why it can be argued that the tourist and recreational geospace also has a systemic organization, it is structured in space and it is a carrier of specific properties that need to be analyzed and studied. Therefore, the result of studying the tourist and recreational space can be an effective management decision-making and the choice of guidelines for the development of the corresponding tourist and recreational territorial entities.

As a result, the tourist and recreational space should be defined as an object of regional policy. In domestic studies, the tourist and recreational space is a part of the space of the country, its social and cultural shell, characterized by the tourist potential of its regions [5].

It should be noted that more attention is paid to public authorities, regional authorities and local governments in many scientific works related to aspects of regional development management, and entrepreneurial structures are practically ignored. Speaking in the context of the problem of the development of tourist and recreational space, the question of entrepreneurial structures of the tourism industry is more urgent than ever. Optimizing economic results, the subjects of the tourism industry contribute to the development of the tourist and recreational territory. The subjects of the tourism industry (entrepreneurship), using the specific properties of the tourist and recreational space, indirectly influence the state and regional policy being the subjects of the regional policy itself. Realizing their investment projects, strategy and tactics, the subjects of the tourism industry, and coinciding in their spatial priorities with state authorities, form regional tourism and recreation clusters [6].

It should be admitted that our federal government does not have a mechanism for effective management of regions and unfortunately their development state authorities do not consider spatial policy to be their priority. In this connection, it seems necessary to consider and study the issue of the formation of the tourist and recreational system with its hierarchical levels of subordination.

The regional nuclei of the subjects of the tourism industry at the municipal level, formed within the framework of the priorities of the regional policy of the state and regional authorities, should become the object of the development of the tourist and recreational space. [7]. 
Examining the territory of our state from space, you can see that as far as people move away from the center, the roads end and economic life dies out. One gets the feeling that it is not possible to change this fragmented space and launch life into remote regions. The lack of mechanisms for the integration and coordination of the activities of various branches and levels of government, regional government, and sometimes competition between regions for «the best place in the sun», hinders interregional interaction and implementation of regional policy priorities.

\section{Discussion. Main part}

The systemic organization of the tourist and recreational space is formed under the influence of the processes of tourist and recreational regional formation and is focal in nature and is implemented through territorial and component-structural processes.

As a result of territorial and structural processes, specialized tourist administrativeterritorial systems are formed - destinations, which, in our opinion, should become the basis and basic element of the tourist-recreational spatial system [8]. At the moment, there is a need to create an understandable structure for the spatial development of tourism with vertical, horizontal and diagonal connections. The institutional structure of the spatial development of tourism will ensure the movement of intellectual processes and the coordination of activities of subordinate structures. In the future a new interaction of government institutions will be formed - federal, regional and municipal on the one hand, and business and civil - on the other hand.

Thus, a tourist destination will be the basis of the methodological approach to the implementation of the principles of passportization, and its structural and logical study will be the basis of the methodology for passportization of tourist and recreational territories.

The purpose of this methodology is to provide the authorities and specialists in the spatial development of the socio-cultural system of the constituent entities of the Russian Federation with a methodological tool and technology for objectifying and systematizing information on the availability of facilities and services in the tourism and recreation sector, which should be unified, understandable and organizational. For the methodological toolkit of the methodology for the spatial development of tourism that is based on the principles of passportization the author proposes the main features of the allocation of administrativeterritorial units of tourist and recreational zoning in space. In turn, units of tourist and recreational zoning of territories in space form the basis of the entire tourist and recreational system with its hierarchical levels along the vertical of interaction.

It is necessary to highlight the territory that will develop according to the basic principles of regional spatial development, within the framework of the regulatory framework, in the process of forming a tourist and recreational system in space, and also in accordance with the existing resource base, highlighting the type of tourism that is most attractive and functional for its territory. By identifying it and making it an object of concentration of the forces of the local population, priorities in the development of a particular area will be created [9]. Various organizational forms of tourist and recreational space will also ensure the process of implementing the set priorities and create an effective redistribution of powers to use regional policy instruments, as well as support management decisions with regulatory legal acts at the municipal level. The agreements reached between the state, regional and local authorities will solve the problems of the regional policy of spatial development of tourism and will become the subject of legal regulation and the object of attention of sectoral and public-professional institutions. 
Table 1. Signs of allocation of administrative-territorial units of tourist-recreational zoning of territories in space and their characteristics. (Author's development).

\begin{tabular}{|c|c|c|}
\hline $\mathrm{p} / \mathrm{p}$ & $\begin{array}{l}\text { Units of tourist and } \\
\text { recreational zoning of } \\
\text { territories in space }\end{array}$ & Characteristics and signs of discharge \\
\hline A & $\begin{array}{l}\text { Tourist and recreational } \\
\text { field } \\
\text { (tourist and recreational } \\
\text { systems - TRS) }\end{array}$ & $\begin{array}{l}\text { The tourist and recreational field is the highest unit of the tourist and recreational } \\
\text { system, a set of the most important organized, stable in space and time connections and } \\
\text { relationships of elements, technologies and factors that ensure its integrity and } \\
\text { controllability. } \\
\text { At the global (international) level } \\
\text { The main distinguishing feature is the sum of tourist and recreational zones. We } \\
\text { select the types of systems: open and closed. }\end{array}$ \\
\hline B & $\begin{array}{l}\text { Tourist and recreational } \\
\text { zone (tourist and } \\
\text { recreational industry - } \\
\text { TRI) }\end{array}$ & $\begin{array}{l}\text { A tourist and recreational zone is a combination of all types of tourist } \\
\text { infrastructure inherent in the tourist and recreational industry (accommodation } \\
\text { facilities, means of transport, public catering facilities, sanatorium treatment and } \\
\text { recreation facilities, attractive facilities and entertainment facilities, educational, } \\
\text { business, medical and recreational, sports and other facilities), subjects of the tourist } \\
\text { market, as well as organizations providing related tourist and recreational services. } \\
\text { At the national level } \\
\text { The main feature of the selection is the sum of tourist and recreational districts } \\
\text { (centers), it is characterized by a certain balance of the tourist and recreational } \\
\text { infrastructure of the subjects of the tourist market, as well as organizations providing } \\
\text { related tourist and recreational services. }\end{array}$ \\
\hline $\mathrm{C}$ & $\begin{array}{l}\text { Tourist and recreational } \\
\text { district (tourist and } \\
\text { recreational center - } \\
\text { TRC) }\end{array}$ & $\begin{array}{l}\text { Tourist and recreational district (center) is the territory of one or several tourist } \\
\text { and recreational complexes that is specialize in the highly efficient implementation of } \\
\text { tourist and recreational services (product). } \\
\text { At the federal level } \\
\text { The sign of allocation is the sum of tourist and recreational complexes that is } \\
\text { characterized by the commonality of historical, cultural, mesoclimatic, socio-economic, } \\
\text { tourist and recreational features of the territory. They determine the balance of } \\
\text { enterprises and organizations of the tourism sector, the potential productivity of } \\
\text { tourism, the physical state of tourist destinations and their competitiveness. }\end{array}$ \\
\hline $\mathrm{D}$ & $\begin{array}{l}\text { Tourist and recreational } \\
\text { region (tourist and } \\
\text { recreational complex - } \\
\text { TRK) }\end{array}$ & $\begin{array}{l}\text { A tourist and recreational region (complex) should be considered as a territory that } \\
\text { is a set of tourist destinations, the single functional task of which is to meet the diverse } \\
\text { needs of people in various types of recreation and travel with the rational use of all } \\
\text { available tourist resources. } \\
\text { At the regional level } \\
\text { The main distinguishing feature is the sum of tourist and recreational destinations } \\
\text { that is characterized by: } \\
\text { - a list of accommodation and catering facilities that meet local conditions; } \\
\text { - features of the information infrastructure; } \\
\text { - the ratio of the subjects of the tourist market; } \\
\text { - types of attractive objects; } \\
\text { - a system of excursion and tourist services; } \\
\text { - the composition of measures for the protection and use of tourist and recreational } \\
\text { resources, etc. }\end{array}$ \\
\hline I & $\begin{array}{l}\text { Tourist and recreational } \\
\text { area (tourist and } \\
\text { recreational destination - } \\
\text { TRD) }\end{array}$ & $\begin{array}{l}\text { A tourist and recreational area is a tourist and recreational space that is } \\
\text { concentrated within certain administrative-territorial boundaries and temporary content. } \\
\text { It is attractive to tourists, has the necessary supporting, support infrastructure, functions } \\
\text { and develops in the interests of local residents and their cultures, as well as it managed } \\
\text { at the level of authorized authorities of the relevant administrative-territorial structures. } \\
\text { At the municipal level } \\
\text { The highlight is the sum of tourist and recreational attractions and related } \\
\text { infrastructure. At the municipal level, determined by the ecological and climatic, } \\
\text { resource compatibility of territories. The boundaries of homogeneous areas are the } \\
\text { external boundaries of homogeneous tourist and recreational areas combined into one } \\
\text { area. }\end{array}$ \\
\hline $\mathrm{F}$ & $\begin{array}{l}\text { Tourist and recreational } \\
\text { site (area) (tourist and } \\
\text { recreational attraction - } \\
\text { TRA) }\end{array}$ & $\begin{array}{l}\text { Tourist and recreational site is one or more tourist attractions, a system of entertainment } \\
\text { and events, the purpose of which is to form a positive experience from the tour. } \\
\text { At the local (local) level } \\
\text { The distinguishing feature is the ecological and climatic, resource compatibility of the } \\
\text { provided tourist and recreational services. The boundaries are established by combining } \\
\text { geological, cultural, historical and other information. }\end{array}$ \\
\hline
\end{tabular}


Government authorities strive to turn tourism into a competitive, innovative, highly profitable sector of the national economy. According to this, state regulation of the tourist services market should be based on the interaction of not only the subjects of the tourism industry, but also should be based on other industry actors and public and professional institutions that promote the coordinated actions of all its participants. The country's leadership strives to create a field of equal opportunities and conditions for competition between participants in the tourism services market: excursion firms, travel agents, tour operators, tourist information centers (TIC), tourists, hotel and restaurant business entities, the transport system and others. Recently, colossal organizational transformations have been taking place that is expressed in changes in the requirements for service, transport support, insurance, safety of tourists in tourist activities that is reflected in the regulatory framework of the considered type of activity at the state and regional level. It not always works at the municipal level where the subjects themselves cannot establish the process of interaction of all participants in the tourism market in its spatial organization. Accordingly, these issues require a more detailed study in order to increase the competitiveness of not only individual firms and territories, but the entire state as a whole.

In this context, the principles of passportization is a necessary process for making reasoned and effective management decisions in the field of forming a mechanism for interaction between public authorities, business structures (business structures), municipal authorities and the population in local communities. As a result, it seems to us necessary to develop a tourist and recreational passport of the municipal formation (TRPMF), which in turn will form the basis of the tourist and recreational portrait (atlas) of the Russian Federation.

The processes of regionalization taking place all over the world are drawing entire regions into a competitive struggle; this is especially evident in the raw materials sector of the economy. The raw materials of the Russian Federation are of great interest in the world economy both now and in the long term. The formation of a correct and effective state policy for the management of various sectoral clusters in space is necessary as state control over many resources is not effective and has been lost in some sectors [10].

By integrating entrepreneurship, socio-political institutions and the local population into the process, the authorities try to interfere in the processes of regional development. The state creates market mechanisms and tries to conduct an effective regional policy at the level of legislative and executive power at various levels of government [11].

As practice shows, federal target programs do not always contribute to the development of the territory. Largely, federal target programs even create «unpleasant» reasons for destructive competition between territories. Regional investments and regional preferences that are allocated within the framework of subsidies do not provide a qualitative improvement in the situation in a particular territory. Uneven development of territories in economic terms has always existed. Federal target programs are ineffectively controlled and regional policy fails because of which a revision of its priorities and means of implementation is required. It is necessary to search for effective regional models and mechanisms for the development of territories in space. This problem is also relevant for the spatial development of tourism. The regional model of territorial development that is based on the principles of passportization of tourist and recreational administrative territorial entities is one of the key issues in the development of territories now. In the light of recent events (post-pandemic situation, development of domestic tourism), new ideas and technologies for developing regional projects, constructive schemes for managing regional processes, monitoring mechanisms and much more are needed [12]. The tourist and recreational passport of the municipality (TRPMF) allows solving a number of important problems, as well as being the basis of digital information and the main aspect of its management. Since the digitalization of business processes in the field of tourism and 
hospitality is based on the processing of large data arrays (Dig date). In this connection, Tourist and Recreational Passports of Municipalities (TRPMF) are of particular relevance. In the era of digitalization and informatization there is a need to introduce a unified digital platform for the development of tourism throughout the country, a component of which will be all the constituent entities of the Russian Federation reporting for the corresponding tourist destinations that are part of their administrative-territorial boundaries [13].

\section{Conclusions}

Due to the social restructuring of modern society, the development of the tourism industry has become a leading trend in the world economy. Macroeconomic research in recent years confirms the trend towards a decrease in the amplitude of fluctuations in the service sector. Therefore, the service sector is increasingly becoming a factor in stabilizing the economy [14].

Thus, the basis for the long-term and sustainable development of tourism as experience shows is precisely the tourist product, and there is the infrastructure associated with the tourist product after it. Therefore, it is necessary to assess all the tourist resources of the territories and rank the territories according to the level of development of the tourism sector (to identify unique territories, territories that require state support and have the potential for tourism development) [15]. The heads of municipalities must form goals and set priorities for the development of tourism in their territories. One of the obstacles hindering the development of tourism at the municipal level is the lack of specialists in the staff of municipal administrations who have knowledges in the development of tourism, as well as the lack of inter-municipal interaction between neighboring territories. For the state authorities, the existing problems of the territories (such as the lack of professional personnel, institutional infrastructure, financial resources and much more) are becoming an increasing burden. The territory of our country has great potential in the development of the tourism and recreation sector. Russia is striving to take a leading position in the world market for the provision of tourist services. The main problem of tourism development is the unevenly developing market of tourist services in certain regions of the country with their unique resource potential. Decision-making at the municipal level on the development of infrastructure, accessibility and provision of attractive facilities will play a significant role in solving this issue. All over the world, the role of municipal and regional regulation in the development of tourism is high. In the Russian Federation, the basic regulation of the problems under consideration is still insufficient. We hope that the proposed approach based on the principles of passportization will make it possible to systematize data on the state of tourist and recreational resources of territories and the natural and anthropogenic factors affecting them.

\section{References}

1. Federal Law «On Strategic Planning in the Russian Federation» dated June 28, 2014, No. 172-FZ (2014)

2. Order of the Government of the Russian Federation «Strategies for the spatial development of the Russian Federation for the period up to 2025» dated 13.02.2019 (2019)

3. O.P. Smirnova, L.M. Averina, Regional Economy: Theory and Practice, 17(6), 1006 -1018 (2019)

4. P.A. Orekhovsky, Bulletin of the Institute of Economics of the Russian Academy of Sciences, 2, 48-67 (2018) 
5. L.N. Leksin, A.N. Shvetsov, State and regions: theory and practice of state regulation of territorial development (Librokom, Moscow, 2012)

6. E. L. Pisarevsky, State and municipal management in the field of tourism (Federal Agency for Tourism, Moscow, 2014)

7. T.A. Malakhova, Regional Economy: Theory and Practice, 17(3), 482 - 493 (2019)

8. T.V. Rassokhina, A.S. Seselkin, Bulletin of the University of the State University of Management, 1, 48-53 (2013)

9. L.V. Parakhina, A.V. Polyanin, T.A. Golovina, Central Russian Bulletin of Social Sciences, 12(5), 48-58 (2017), URL: https://doi.org/10.22394/2071-2367-2017-12-548-58

10. N.V. Neveikina, Scientific notes of the Oryol State University. Series: Humanities and Social Sciences, 1, 78-85 (2014), URL: https://cyberleninka.rU/article/v/faktoryrazvitiya-regiona

11. T.B. Bardakhanova, Z.S. Eremko, L.B.-J. Maksanova, Regional Economy: Theory and Practice, 17(4), 789 - 800 (2019), https://doi.org/10.24891/re. 17.4.789

12. C.A. Grachev, O.A. Donichev, A.S. Levizov, Regional Economy: Theory and Practice, 17(5),804 - 817 (2019)

13. E.B. Popov, K.A. Semyachkov, Regional Economy: Theory and Practice, 16(7), 1320-1337 (2018), URL: https://doi.Org/10.24891/re.16.7.1320/

14. N.V. Kashina, Economy of the Region, 1(2), 569-585 (2016), URL: https://cyberleninka.ru/article/v/territorii-operezhayuschego-razvitiya-novyymstrument-privlecheniya-investitsiy-na-dalniy-vostok-rossii

15. T.A. Malakhova, Regional Economy: Theory and Practice, 17(3), 482 - 493 (2019) 